\title{
NUTRITIONAL STATUS OF DECLINING SPRUCE (Picea abies (L.) \\ Karst.): EFFECT OF SOIL ORGANIC MATTER TURNOVER RATE
}

\author{
ALAIN HAMBUCKERS and JEAN REMACLE \\ Microbial Ecology, University of Liège, B22 Sart Tilman, 4000 Liège, Belgium
}

(Received March 20, 1990; revised March 12, 1991)

\begin{abstract}
Foliar analysis was undertaken in two plots of Picea abies (L.) Karst., located in a watershed of Haute Ardenne, Belgium, in order to estimate the decline of the trees. Apart from a general $\mathrm{Mg}$ deficiency, the concentrations of the needles were in the same range as those determined in other European stands. Comparisons between healthy and declining trees within each plot revealed a general pattern of decline similar to that observed elsewhere in Western Europe. This was shown as lower $\mathrm{Ca}, \mathrm{Mg}$, $\mathrm{Zn}$ concentrations and water content and higher $\mathrm{N}$ and $\mathrm{P}$ concentrations of the needles collected from declining trees. It is concluded that this decline could be due to $\mathrm{N}$ over fertilization by the atmospheric deposition. The difference of decline between the two plots was attributed to the turnover rate of the soil organic layer which was less intensive in the most damaged plot.
\end{abstract}

\section{Introduction}

Nutrient fluxes have been studied since 1980 in a Norway spruce Picea abies (L.) Karst. watershed located in the Haute Ardenne region, Belgium (Buldgen et al, 1984). As the forest growth induces an impoverishment of the soil nutrient pool, this approach can be used to determined how natural ageing of the forest effects nutrient cycling. However, spruce decline was first reported in the Haute Ardenne region in 1982 (Weissen et al., 1983) and infra-red aerial pictures of the watershed showed a significant increase of trees with symptoms of decline between 1983 and 1984 (Farcy, C. and Maréchal, P., personal communication). On the one hand, the forest decline could be associated with nutrient cycling changes in forested watersheds (Hauhs and Wright, 1986). On the other hand, the alteration of forest vitality could be related to soil perturbations inducing changes in the nutritional status of the trees (Ulrich et al., 1980; Andersson, 1986; Matzner et al., 1986; Kandler et al., 1987; Oren et al., 1988a, b; Hauhs and Ulrich, 1989; Schulze, 1989).

In this work, the nutritional status of the trees was examined in relation to their vitality and the properties of the surrounding soil in order to investigate the occurrence of decline in the watershed. The observations were conducted on two plots stocked by spruce of two age classes ( 55 yr-old and 95 yr-old).

\section{Material and Methods}

The plots were located in the watershed 'La Robinette', as previously described (Buldgen et al., 1984). The first plot (plot A) comprises 7.5 ha and is stocked with 55 yr-old-trees (483 trees ha ${ }^{-1}$ ) while the other one (plot B) is 12 ha and is stocked with 95 yr-old trees (288 trees ha ${ }^{-1}$ ). 
The ground vegetation was very poor in plot $\mathrm{A}$, while plot $\mathrm{B}$ has a $50 \%$ cover, It was chiefly composed of Molinia caerulea (L.) Moench, Polytrichum commune (L.), Vaccinium myrtillus (L.), Deschampsia flexuosa (L.) Trin. and Pteridium aquilinum (L.) Khun.

The trees showing symptoms of decline, needle yellowing and loss, were spread throughout the plots. However, the symptoms were less distinct in plot B where trees with abundant yellow needles were sometimes well needled, while the needles of trees with higher needle loss were often green. Needles were collected in December 1987 from 8 trees in each plot. As the branches were cut by hand, it was difficult to increase the number of sampled trees because climbing was particularly dangerous. However, it seems that it would be enough for the assessment of the nutrient status since Bonneau (1988) recommends 10 trees per plot. Four trees showing no decline symptoms and 4 damaged trees were sampled in plot $\mathrm{A}$ while 3 trees showing no decline symptoms and 5 damaged trees were samples in plot B. The current needles and needles of the three preceding growing periods were randomly taken, when present, from one branch of the 5 th, 10 th and 15 th verticils. Needles older than $4 \mathrm{yr}$ were very rare. The needles were ashed in a mixture of $\mathrm{HNO}_{3}, \mathrm{HClO}_{4}$ and HF (4/1/0.5, V/V/V) in teflon vessels according to Van Loon (1985). The solutions were taken to dryness, and the ash dissolved in $6 \mathrm{~N} \mathrm{HCl} . \mathrm{Ca}, \mathrm{Mg}, \mathrm{K}$, $\mathrm{Fe}, \mathrm{Zn}, \mathrm{Na}$ and $\mathrm{Al}$ were determined by flame spectrometry; $\mathrm{Pb}$ and $\mathrm{Cd}$ by graphite furnace spectrometry and total $\mathrm{S}$ by nephelometry. Total $\mathrm{N}$ and $\mathrm{P}$ were assessed colorimetrically after Kjeldhal digestion following Schneider (1976) and APHA (1980). Ammonium concentrations were estimated only on the needles collected from the branches of the 10th verticil in a $0.5 \mathrm{M} \mathrm{KCl}$ extract by the micro-diffusion method of Bremner (1965). The chlorophylls contents were determined according to Bruinsma (1963).

The nutrient status of the soil was studied by determining the exchangeable cations. The decomposition of the humus layers was compared on the ground of the thickness and the CEC. The nutrient supply to the soil pool by the humus layers was estimated by analyzing the leachates under these layers. The soil sampling scheme was conducted following the judgement sampling method outlined by Petersen and Calvin (1965); it means that the soil was randomly sampled from both sites but in similar areas which were free of ground vegetation. For the analysis, ten soil samples of $400 \mathrm{~cm}^{2}$ were taken from the organic layer $(\mathrm{Ol}+\mathrm{Of}+\mathrm{Oh})$ and from the two 10 $\mathrm{cm}$ thick deeper layers. Each sample was homogenized before a subsample was taken for analysis. Exchangeable cations were determined in soil extract obtained after shaking $10 \mathrm{~g}$ of dry soil in $100 \mathrm{~mL} 1 \mathrm{M} \mathrm{NaCl}$ for $15 \mathrm{hr}$; exchangeable acidity was determined as the $\mathrm{pH}$ of this solution. Cation exchange capacity was assessed following Aubert (1978). Ten g of humus layers were leached with $500 \mathrm{~mL} 1 \mathrm{~N}$ $\mathrm{CaCl}_{2}$ buffered with $0.11 \mathrm{M}$ triethanolamine-HNO $\mathrm{HNH}_{3}$ ( $)$ overnight. The excess of $\mathrm{CaCl}_{2}$ was washed with distilled water and the $\mathrm{Ca}$ was extracted by shaking the soil in $100 \mathrm{~mL} 1 \mathrm{M} \mathrm{NaCl}$ for $15 \mathrm{hr}$. Leachates under the humus layers were collected monthly from 16 root-free lysimeters of $283.5 \mathrm{~cm}^{2}$ (Buldgen et al., 1983) 
located in both plots. Cations and other nutrient concentrations, organic $\mathrm{C}$ in the leachates and in soil extracts were determined as described elsewhere (Buldgen et al., 1983).

Comparisons of mean were performed following the Wilcoxon range test as described in SAS (1985). Variance analysis was computed by the GLM procedure (SAS, 1985) which handles unbalanced data sets. Significance was assumed when the probability to observe a larger score of $|Z|$ or $|F|$ under the null hypothesis (absence of difference) was smaller than the usual levels $(0.10,0.05,0.01)$. The data were pooled on the basis of tree age and/or health status to compute the means and determine the sign of the differences.

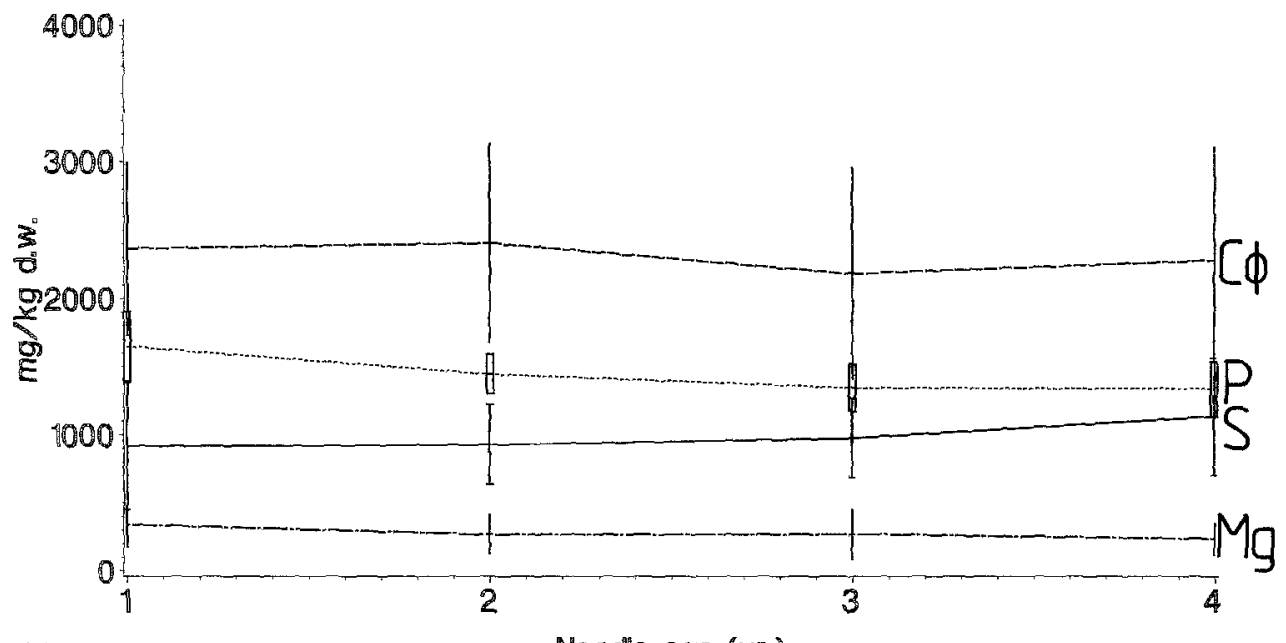

(a)

Needle age (yr.)

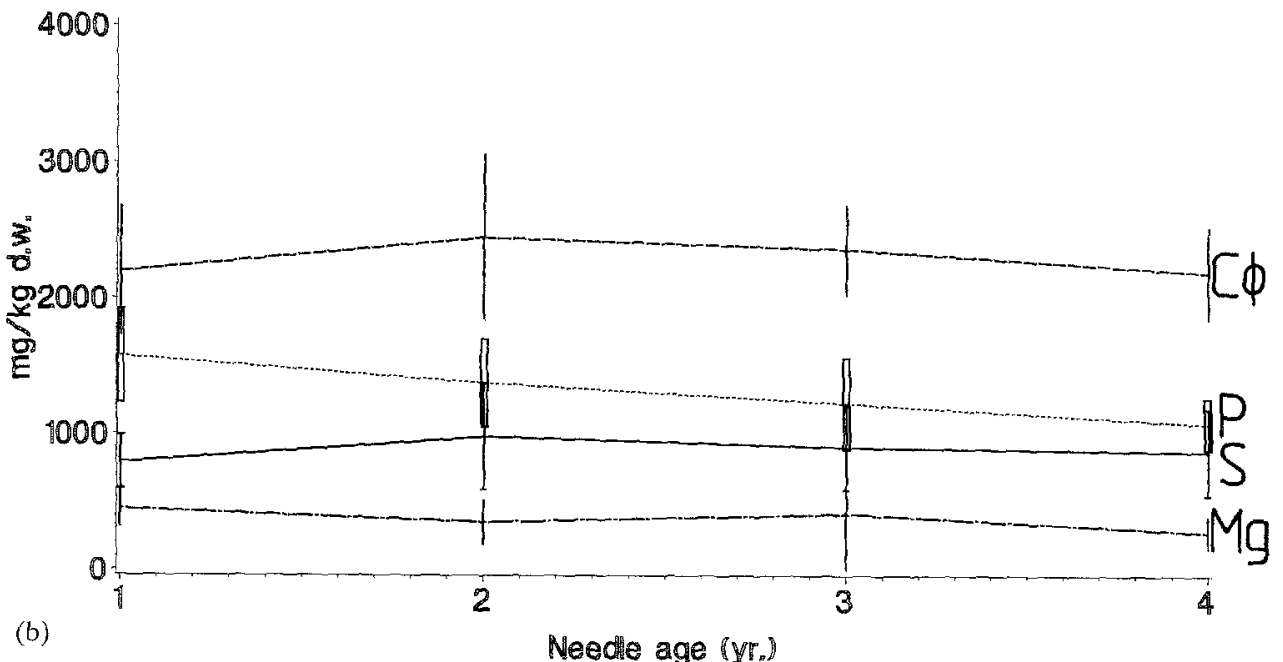

Fig. 1. Means and standard deviations of the concentrations of chlorophylls (c $\Phi$ ), total $\mathrm{P}, \mathrm{S}$ and $\mathrm{Mg}$ determined in the needles collected from the trees of the plot A (Figure 1a) and the plot B (Figure 1B) vs the needle age. 


\section{Results}

The needle content of chlorophylls and major nutrients is shown in the Figures 1 and 2. It cannot be concluded that significant trends occur for most of the nutrient and chlorophyll concentrations since the standard deviations were large and the composition of the 1 to 4 yr-old needles was only assessed. Therefore, comparisons of mean of the nutrient and chlorophyll concentrations and the water contents of the needles were performed by variance analysis. The effects of age class (55
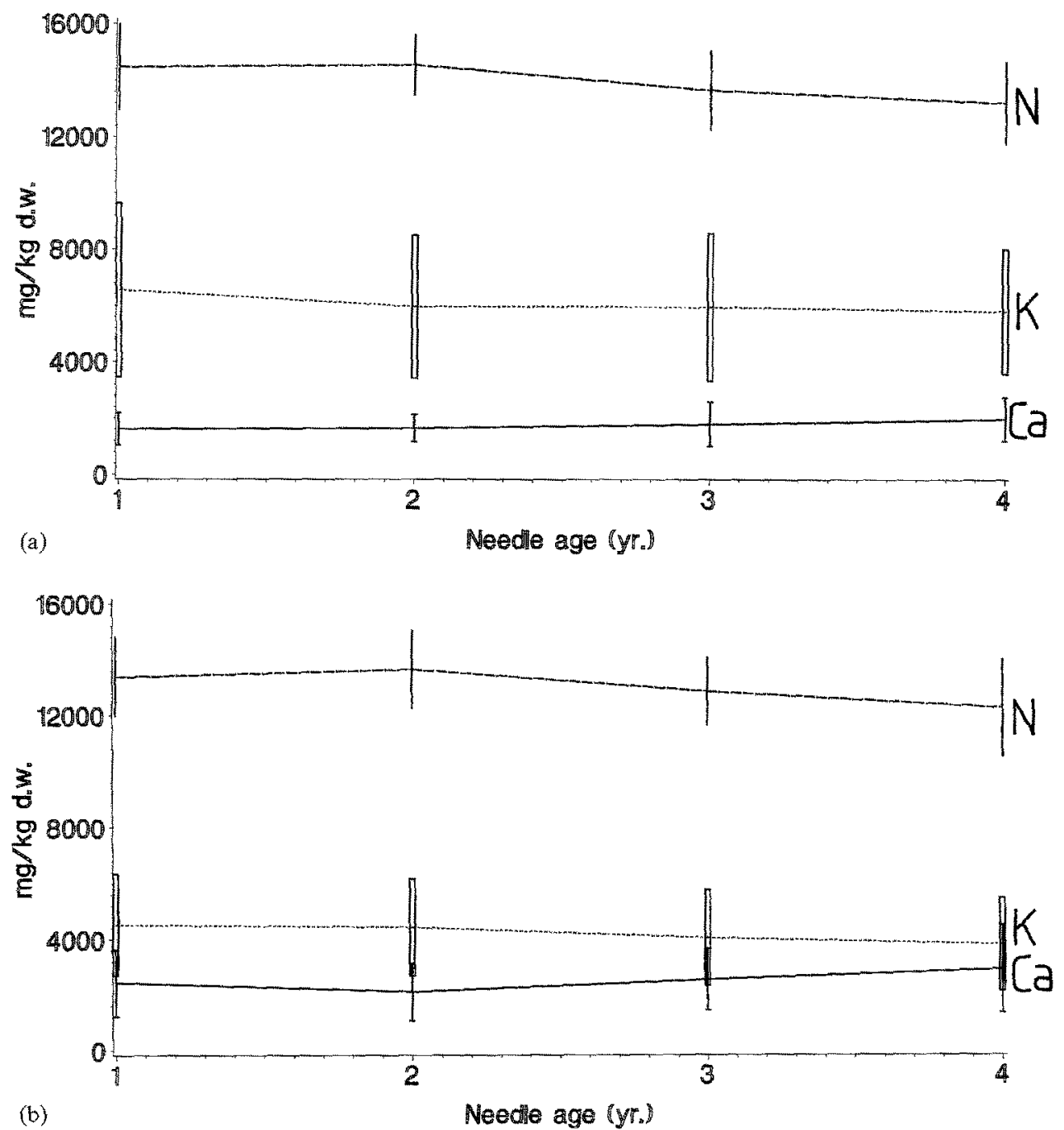

Fig. 2. Means and standard deviations of the concentrations of total $\mathrm{N}, \mathrm{Ca}$ and $\mathrm{K}$ determined in the needles collected from the trees of the plot A (Figure $2 \mathrm{a}$ ) and the plot B (figure $2 b$ ) vs the needle age. 
yr-old and 95 yr-old) and tree vitality (healthy or declining trees) were tested in a four-way factorial model including also needle age and verticil. Only the results concerning the age class and the tree vitality are presented (Table I). By assuming a Gaussian distribution, it appeared at the 0.05 level that the content of chlorophylls, ammonium, $\mathrm{Zn}$, and $\mathrm{Pb}$ only depended on the health status and the content of $\mathrm{Ca}, \mathrm{Fe}$ and $\mathrm{Cd}$ was related to the age of the trees; both the health status and the age affected total $\mathrm{P}$ and $\mathrm{N}, \mathrm{Mg}$ and $\mathrm{K}$. Table II shows that the declining trees were characterized by lower needle contents of chlorophylls, $\mathrm{Mg}$ and $\mathrm{Zn}$ and higher contents of total $\mathrm{N}$ and $\mathrm{P}$, ammonium, $\mathrm{K}$ and $\mathrm{Pb}$. Table II also shows that the needles of the $95 \mathrm{yr}$-old trees had higher levels of $\mathrm{Ca}, \mathrm{Mg}$ and $\mathrm{Fe}$ and lower levels of total $\mathrm{P}$ and $\mathrm{N}, \mathrm{K}$ and $\mathrm{Cd}$. The plots were also assessed separately to show the effect of health status, discarding the tree age influence. Three-way variance analysis were performed including the effects of health status, needle age and verticil. Table III shows that healthy trees in the plot A differ from the declining ones by having higher water contents and higher concentrations of chlorophylls, $\mathrm{Ca}$, $\mathrm{Mg}, \mathrm{Al}, \mathrm{Na}$ and $\mathrm{Zn}$ and lower concentrations of $\mathrm{K}$ and $\mathrm{Pb}$, while only small differences occurred in the $\mathrm{P}$ concentrations. The healthy trees in the plot $\mathrm{B}$ also showed lower concentrations of $\mathrm{K}, \mathrm{N}$ and $\mathrm{P}$ and to a less extent of ammonium (Table IV).

Forest ageing could influence the turnover of organic matter and thus the characteristics of the soil. For this reason, the humus layers of the plots were characterized by the thickness, the CEC, the exchangeable cations, the exchangeable acidity and the composition of the leaching solution. The exchangeable cations

\section{TABLE I}

Four-way variance analysis of water content, chlorophyll and mineral concentrations of the needle including the effects of health status, plot, needle verticil (except ammonium) and needle age: effects of health status and plot (probability to observe a larger $|F|$ under null hypothesis than the observed

$|F|$ : health status, $P>\left|F_{h s}\right|$; plot, $\left.P>\left|F_{\text {plot }}\right|\right)$.

\begin{tabular}{lll}
\hline & $P>\left|F_{h s}\right|$ & $P>\left|F_{\text {plot }}\right|$ \\
\hline Water content & 0.0919 & 0.0801 \\
Chlorophylls & 0.0001 & 0.4367 \\
Total N & 0.0077 & 0.0001 \\
Total P & 0.0001 & 0.0007 \\
Total S & 0.3067 & 0.0622 \\
Ammonium-N & 0.0508 & 0.1190 \\
$\mathrm{Ca}$ & 0.8002 & 0.0001 \\
$\mathrm{Mg}$ & 0.0001 & 0.0005 \\
$\mathrm{~K}$ & 0.0001 & 0.0001 \\
$\mathrm{Al}$ & 0.0612 & 0.9093 \\
$\mathrm{Fe}$ & 0.2258 & 0.0282 \\
$\mathrm{Na}$ & 0.1885 & 0.7954 \\
$\mathrm{Zn}$ & 0.0041 & 0.9860 \\
$\mathrm{~Pb}$ & 0.0043 & 0.2395 \\
$\mathrm{Cd}$ & 0.1421 & 0.0369 \\
\hline
\end{tabular}




\section{TABLE II}

Means values of water content (\% of fresh weight), chlorophyll and mineral concentrations (mg kg-1 of dry weight) of the needles collected from healthy or declining trees and from plot A or plot B. For significance of comparison, see Table I.

\begin{tabular}{lccccc}
\hline & \multicolumn{2}{c}{ Plot A Plot B } & & \multicolumn{2}{c}{ Healthy + declining } \\
\cline { 2 - 3 } \cline { 5 - 6 } & Healthy & Declining & & Plot A & Plot B \\
\hline Water content & 55.1 & 53.9 & & 55.1 & 53.7 \\
Chlorophylls & 2613 & 2113 & & 2430 & 2299 \\
Total N & 13307 & 13956 & & 14188 & 12590 \\
Total P & 1284 & 1441 & & 1441 & 1290 \\
Total S & 901 & 954 & & 978 & 877 \\
Ammonium-N & 91.5 & 105.7 & & 93.4 & 103.8 \\
$\mathrm{Ca}$ & 2123 & 2100 & & 1774 & 2438 \\
$\mathrm{Mg}$ & 394 & 272 & & 286 & 380 \\
$\mathrm{~K}$ & 4038 & 5971 & & 5929 & 4082 \\
$\mathrm{Al}$ & 176 & 148 & & 165 & 159 \\
$\mathrm{Fe}$ & 160 & 168 & & 158 & 170 \\
$\mathrm{Na}$ & 184 & 153 & & 171 & 167 \\
$\mathrm{Zn}$ & 21.5 & 18.6 & & 20.4 & 19.8 \\
$\mathrm{~Pb}$ & 0.61 & 0.76 & & 0.71 & 0.66 \\
$\mathrm{Cd}$ & 0.17 & 0.20 & & 0.20 & 0.17 \\
\hline
\end{tabular}

\section{TABLE III}

Mean values of water content (\% of fresh weight), chlorophyll and mineral concentrations ( $\mathrm{mg} \mathrm{kg}^{-1}$ of dry weight) of the needles collected from healthy and declining trees of plot $\mathrm{A}$ and three-way variance analysis including the effects of health status, needle verticil (except ammonium) and needle age: effect of health status (probability to observe a larger $|F|$ under null hypothesis than the observed $\left|F_{h s}\right|: P>\left|F_{h s}\right|$

\begin{tabular}{lccl}
\hline & Healthy & Declining & $P>\left|F_{h s}\right|$ \\
\hline Water content & 56.2 & 54.0 & 0.0001 \\
Chlorophylls & 2972 & 1882 & 0.0001 \\
Total N & 14079 & 14277 & 0.5280 \\
Total P & 1404 & 1470 & 0.1029 \\
Ammonium-N & 87.2 & 99.6 & 0.02978 \\
$\mathrm{Ca}$ & 2007 & 1527 & 0.0003 \\
$\mathrm{Mg}$ & 378 & 193 & 0.0001 \\
$\mathrm{~K}$ & 4623 & 7233 & 0.0001 \\
$\mathrm{Al}$ & 200 & 129 & 0.0027 \\
$\mathrm{Fe}$ & 157 & 159 & 0.8331 \\
$\mathrm{Na}$ & 223 & 118 & 0.0102 \\
$\mathrm{Zn}$ & 24.0 & 16.8 & 0.0001 \\
$\mathrm{~Pb}$ & 0.57 & 0.84 & 0.0002 \\
$\mathrm{Cd}$ & 0.18 & 0.22 & 0.2865 \\
\hline
\end{tabular}




\section{TABLE IV}

Mean values of water content ( $\%$ of fresh weight), chlorophyll and mineral concentrations (mg kg-1 of dry weight) of the needles collected from healthy and declining trees of plot $B$ and three-way variance analysis including the effects of health status, needle verticil (except ammonium) and needle age: effect of health status (probability to observe a larger $|F|$ under null hypothesis than the observed $\left|F_{h s}\right|: \mathrm{P}>\left|F_{h s}\right|$

\begin{tabular}{lccc}
\hline & Healthy & Declining & $P>\left|F_{h s}\right|$ \\
\hline Water content & 53.8 & 53.7 & 0.9568 \\
Chlorophylls & 2249 & 2332 & 0.4084 \\
Total N & 12537 & 13634 & 0.0024 \\
Total P & 1164 & 1413 & 0.0001 \\
Total S & 848 & 906 & 0.3941 \\
Ammonium-N & 95.8 & 111.8 & 0.1006 \\
$\mathrm{Ca}$ & 2219 & 2662 & 0.1299 \\
$\mathrm{Mg}$ & 410 & 351 & 0.2465 \\
$\mathrm{~K}$ & 3447 & 4701 & 0.0007 \\
$\mathrm{Al}$ & 152 & 166 & 0.5597 \\
$\mathrm{Fe}$ & 163 & 176 & 0.1292 \\
$\mathrm{Na}$ & 145 & 188 & 0.1553 \\
$\mathrm{Zn}$ & 18.9 & 20.7 & 0.1880 \\
$\mathrm{~Pb}$ & 0.64 & 0.67 & 0.7025 \\
$\mathrm{Cd}$ & 0.16 & 0.17 & 0.2453 \\
\hline
\end{tabular}

and the exchangeable acidity were also determined on the 0 to 10 and 10 to 20 $\mathrm{cm}$ deep mineral soil. The thickness of the organic layer was significantly higher in plot A than in plot B (Table V). According to Duchafour (1977), CEC increases as the degree of humification but it did not differ significantly between the both plots. The exchangeable Ca was significantly higher in the organic layer of the plot $\mathrm{B}$ while in the deeper soil layers, the exchangeable $\mathrm{Fe}$ was higher and the exchangeable $\mathrm{Cd}$ was lower. Leachates under the organic layer showed significant differences between the plots (Table VI). At the 0.05 level, ammonium, $\mathrm{Ca}, \mathrm{Mg}$, $\mathrm{Fe}, \mathrm{Na}$ and organic $\mathrm{C}$ were significantly more concentrated in the leachates of plot B while nitrate was less concentrated.

\section{Discussion}

Table I shows that the needle concentrations of the major nutrients $\mathrm{N}, \mathrm{P}, \mathrm{Ca}, \mathrm{Mg}$, and $\mathrm{K}$ could be controlled in part by the tree age or the characteristics of the plot. It corroborated the conclusions of Oren et al. (1988a) who stressed the point that the nutrient concentration of the foliage always reflects the site characteristics more than the symptoms of decline. Moreover, individual heterogeneity, microvariability in soil fertility, combined with social status and genetical diversity of trees were important factors which influence the extent of the decline of individual trees or their nutrient status in each plot.

However it seems that general comparisons can be made by reference to data collected in other forests in order to establish the nutritional status of the sites 


\section{TABLE V}

Soil organic layer thickness (cm, $N=100), \mathrm{CEC}\left(\mathrm{mmol}_{c} \mathrm{~kg}^{-1}\right.$ of dry soil, $N=10$ ), exchangeable acidity (pH, $N=10$ ), exchangeable cations ( $\mathrm{mmol}_{\mathrm{c}} \mathrm{kg}^{-1}$ of dry soil, $N=10$ ) in plot A and plot $\mathrm{B}$, and Wilcoxon range test (probability to observe a larger $|Z|$ under null hypothesis than observed $|Z|: P>|Z|$ )

\begin{tabular}{|c|c|c|c|}
\hline & Plot $A$ & Plot B & $P>|Z|$ \\
\hline \multicolumn{4}{|l|}{ Organic layer } \\
\hline Thickness & 8.43 & 5.43 & 0.0000 \\
\hline $\mathrm{CEC}$ & 259 & 272 & 0.5708 \\
\hline Acidity & 3.49 & 3.53 & 0.4265 \\
\hline Ammonium & 9.14 & 9.21 & 0.9097 \\
\hline $\mathrm{Ca}$ & 12.30 & 30.05 & 0.0757 \\
\hline $\mathrm{Mg}$ & 7.87 & 9.14 & 0.2413 \\
\hline $\mathrm{K}$ & 9.74 & 10.74 & 0.2413 \\
\hline $\mathrm{Al}$ & 70.78 & 58.11 & 0.1211 \\
\hline $\mathrm{Fe}$ & 21.90 & 28.07 & 0.3447 \\
\hline $\mathrm{Zn}$ & 1.06 & 1.29 & 0.1405 \\
\hline $\mathrm{Pb}$ & 1.90 & 2.10 & 0.9097 \\
\hline $\mathrm{Cd}$ & 0.02 & 0.01 & 0.3254 \\
\hline \multicolumn{4}{|c|}{0 to $10 \mathrm{~cm}$ under the organic layer } \\
\hline Acidity & 3.71 & 3.75 & 0.6775 \\
\hline Ammonium & 6.79 & 5.96 & 0.5205 \\
\hline $\mathrm{Ca}$ & 1.14 & 2.32 & 0.5205 \\
\hline $\mathrm{Mg}$ & 3.60 & 4.35 & 0.1859 \\
\hline K & 4.48 & 5.14 & 0.3847 \\
\hline $\mathrm{Al}$ & 82.78 & 77.67 & 0.1303 \\
\hline $\mathrm{Fe}$ & 18.09 & 45.20 & 0.0002 \\
\hline $\mathrm{Zn}$ & 0.59 & 0.48 & 0.6232 \\
\hline $\mathrm{Pb}$ & 1.34 & 1.56 & 0.3843 \\
\hline $\mathrm{Cd}$ & 0.04 & 0.01 & 0.0017 \\
\hline \multicolumn{4}{|c|}{10 to $20 \mathrm{~cm}$ under the organic layer } \\
\hline Acidity & 3.94 & 4.04 & 0.5205 \\
\hline Ammonium & 3.91 & 3.60 & 0.8205 \\
\hline $\mathrm{Ca}$ & 0.54 & 0.54 & 0.7913 \\
\hline $\mathrm{Mg}$ & 1.83 & 2.26 & 0.3847 \\
\hline $\mathrm{K}$ & 2.69 & 2.94 & 0.4274 \\
\hline $\mathrm{Al}$ & 70.44 & 73.56 & 1.0000 \\
\hline $\mathrm{Fe}$ & 8.43 & 27.70 & 0.0002 \\
\hline $\mathrm{Zn}$ & 0.38 & 0.28 & 0.9698 \\
\hline $\mathrm{Pb}$ & 0.57 & 0.69 & 0.3642 \\
\hline $\mathrm{Cd}$ & 0.03 & 0.02 & 0.2411 \\
\hline
\end{tabular}


TABLE VI

Water fluxes $\left(\mathrm{mm} \mathrm{d}^{-1}\right)$, mean concentrations $\left(\mathrm{mg} \mathrm{L}^{-1}\right)$ and $\mathrm{pH}$ of the leachates collected under organic layer of plot $\mathrm{A}$ and plot $\mathrm{B}$, number of observations $(N)$ and Wilcoxon range test (probability to observe a larger $|Z|$ under null hypothesis than observed $|Z|: P>|Z|$ )

\begin{tabular}{lccccc}
\hline & Plot A & $\mathrm{N}$ & Plot B & $\mathrm{N}$ & $\mathrm{P}>|Z|$ \\
\hline Water fluxes & 2.53 & 425 & 2.50 & 429 & 0.9025 \\
Ammonium-N & 10.9 & 416 & 13.0 & 418 & 0.0001 \\
Nitrate-N & 7.93 & 417 & 6.27 & 418 & 0.0004 \\
$\mathrm{Ca}$ & 1.63 & 418 & 1.73 & 421 & 0.0001 \\
$\mathrm{Mg}$ & 0.56 & 418 & 0.64 & 421 & 0.0135 \\
$\mathrm{~K}$ & 3.19 & 418 & 3.12 & 420 & 0.9728 \\
$\mathrm{Al}$ & 1.35 & 96 & 1.32 & 95 & 0.7071 \\
$\mathrm{Fe}$ & 1.03 & 418 & 1.90 & 420 & 0.0000 \\
$\mathrm{Na}$ & 3.00 & 418 & 3.46 & 421 & 0.0001 \\
$\mathrm{Zn}$ & 0.21 & 96 & 0.22 & 95 & 0.7792 \\
$\mathrm{~Pb}$ & 0.077 & 96 & 0.064 & 95 & 0.0993 \\
$\mathrm{Cd}$ & 0.0038 & 96 & 0.0054 & 95 & 0.8845 \\
$\mathrm{pH}$ & 3.53 & 424 & 3.60 & 424 & 0.2879 \\
Organic-C & 50.7 & 365 & 58.2 & 370 & 0.0005 \\
Phosphate-P & 0.44 & 418 & 0.45 & 420 & 0.0925 \\
Sulphate-S & 2.49 & 416 & 2.51 & 420 & 0.9876 \\
\hline
\end{tabular}

under study. The needles from both plots were characterized by normal or sufficient levels of total $\mathrm{N}, \mathrm{P}, \mathrm{S}, \mathrm{Ca}, \mathrm{Fe}, \mathrm{Zn}, \mathrm{Pb}, \mathrm{Cd}$ and $\mathrm{Al}$ (Tables II, III and IV) according to the values and the step values of Weissen et al. (1983), Reemstma (1986), Van Praag and Weissen (1986), Wyttenbach et al. (1985), Zöttl and Hüttl (1986), Forschner and Wild (1987), Kandler et al. (1987), Bonneau (1988), Oren et al. (1988a). Potassium concentrations appeared also to be sufficient except for the healthy trees of plot B where they were below the critical value suggested by Bonneau (1988) and Zöttl and Hüttl (1986). All the Mg concentrations were below the critical value of these authors. The Na contents were higher than the value determined by Wyttenbach et al. (1985). These authors have shown that the foliar pool is highly dependent upon the atmospheric deposition. The high $\mathrm{Na}$ levels could therefore result from the fact that the site mainly receives precipitations with westerly winds loaded with sea spray. Water contents of the needles were lower than the values obtained by Badot et al. (1988) but these values were dependent upon the sampling time and the season. The mineral levels determined in the needles showed two factors: (I) the occurrence of a $\mathrm{Mg}$ deficiency which was already described in the Haute Ardenne region (Weissen and Van Praag, 1982); (II) the total S concentration in the needles was well below the level of toxicity i.e. $1900 \mathrm{mg} \mathrm{kg}^{-1}$ of dry needles (Knabe, 1984) or of $1500 \mathrm{mg} \mathrm{kg}^{-1}$ (Bonneau, 1988) which suggests that the forest was not polluted by $\mathrm{SO}_{2}$.

In other respects, most of the differences in concentrations between the needles of healthy and declining trees suggest that the decline occurring in the watershed should be related to the observations made in Western Europe. Lower Ca and 
$\mathrm{Mg}$ concentrations have been often reported in the needles collected from declining trees by comparison with healthy ones (Van Praag et al., 1986; Zöttl and Hüttl, 1986; Forschner and Wild, 1987; Kandler et al., 1987; Badot et al., 1988; Oren et al., 1988a; Schulze, 1989); the same differences were also reported for water content (Badot et al., 1988), Zn (Zöttl and Hüttl, 1986) and chlorophylls (Kandler et al., 1987). Otherwise, the difference in $\mathrm{K}$ concentration between the needles of declining and healthy trees is assumed to originate from cation antagonism between $\mathrm{Ca}, \mathrm{Mg}$ and $\mathrm{K}$ (Leggett and Gilbert, 1969). Al should not be a problem in those sites since exchangeable $\mathrm{Al}$ is in the range of other Belgian soils (Van Praag and Weissen, 1985) and Van Praag et al. (1985) have shown that the Al status encountered in the Ardenne soils does not inhibit the development of spruce.

Schulze (1989) suggested that the atmospheric deposition of ammonium, nitrate and sulphate disturbs the mineral nutrition of the tree; spruce roots take up ammonium rather than nitrate, with antagonistic effect on uptake of $\mathrm{Mg}$. Moreover, the deposition of nitrate and sulphate would accelerate the soil acidification, decreasing the $\mathrm{Ca} / \mathrm{Al}$ and $\mathrm{Mg} / \mathrm{Al}$ ratios and affecting the root development and the water and nutrient uptake. Finally, canopy uptake of atmospheric $\mathrm{N}$, in addition to root uptake, would stimulate growth and cause $\mathrm{N}$ imbalance. It was shown that excessive ammonium supply results on the one hand in higher ammonium, total $\mathrm{N}$ and $\mathrm{P}$ contents and on the other hand in lower $\mathrm{Ca}, \mathrm{Mg}$ and $\mathrm{K}$ contents (Haynes and Goh, 1978; Findenegg, 1987). As the needles of the declining trees exhibited most of the same trends, except $\mathrm{K}$, our observations fit to the Schulze model (1989). Two following observations support this hypothesis: (I) the total wet deposition of $\mathrm{N}$ in the open rain on the watershed would be as high as 28 $\mathrm{kg} \mathrm{ha}^{-1} \mathrm{yr}^{-1}$ (Weissen et al., 1990); (II) it was previously assumed that on this site, ammonium could be taken up by the needles as the ammonium throughfall deposition was lower than open site deposition (Hambuckers and Remacle, 1987).

Lead and $\mathrm{Cd}$ contents of the needles as well as differences in concentration between healthy and declining trees lead us to suggest that these metals could also be implicated in the process of decline. It has been shown that increased heavy metal concentrations in the soil solution could result in decrease chlorophyll concentrations and root elongation (Mitchell and Fretz, 1977; Godbold et al., 1987; Godbold and Hütterman, 1986; Schlegel et al., 1988). However, the concentrations used in these experiments were often higher than the in situ level and it must be pointed out that the synergistic effects occurring in forest environment were also not taken into account.

The symptoms of decline (needle yellowing and loss) allow the conclusion that the plot $\mathrm{B}$ was less damaged than the plot $\mathrm{A}$. However, this is not supported by the lower $\mathrm{K}$ contents of the needles of plot $\mathrm{B}$ (Tables II) but is by the higher $\mathrm{Ca}$ and $\mathrm{Mg}$ concentrations and the lower $\mathrm{P}$ and $\mathrm{N}$ concentrations. The same differences in the concentration of mineral elements of the needles were observed between the plots as between the healthy and declining trees. The overall higher vitality of plot B could be the result of a better turnover of the organic layer. This is supported by the following observations. The organic layer was thinner 
in plot B than in plot A (Table V). Martinez et al. (1980) observed that microbial activities were more intensive in thinner litter layers. Therefore a better supply to the nutrient pool in the soil should exist. Since the water fluxes through the humus layers in the lysimeters were not significantly different in both plots (Table $\mathrm{VI}$ ), the comparison of the nutrient concentrations in the leachates reflect the nutrient supply of the humus. The leachates of plot $\mathrm{B}$ had higher concentrations of ammonium, $\mathrm{Ca}, \mathrm{Mg}, \mathrm{Fe}, \mathrm{Na}$ and organic $\mathrm{C}$ and lower concentrations of nitrate (Table VI). This may have resulted from the microbial activity which promoted the ammonium and soluble organic $\mathrm{C}$ production, this latter production inhibiting the mobilization of nitrate (Buldgen et al., 1982) and enhancing the release of Fe (Buldgen et al., 1983). In addition, the higher exchangeable $\mathrm{Ca}$ in the organic layer of plot $\mathrm{B}$ indicated that the $\mathrm{Ca}$ mineralization was greater, and the higher exchangeable $\mathrm{Fe}$ in the deeper soil layers of plot B than in plot A (Table V), gave evidence of increased amount of $\mathrm{Fe}$ transported by organic $\mathrm{C}$.

The better turnover of the organic matter in the plot $B$ should be the consequence of the tree density. This was lower in plot B than in plot A (288 and 483 trees ha ${ }^{-1}$, respectively). This means that more light could reach the ground in plot $\mathrm{B}$, which was shown by the enhanced growth of the ground vegetation. The litter receiving more energy, the decomposition and the release of nutrients should be higher through microbial activity, inducing a better physiological response of the trees against the environmental stresses.

\section{Conclusions}

Foliar analysis showed a general pattern of typical forest decline. In the needles of the declining trees, enhanced ammonium, total $\mathrm{N}$ and total $\mathrm{P}$ levels, in combination with lower base cation concentrations, suggest physiological responses to $\mathrm{N}$ overfertilization by the atmospheric deposition. The difference of decline state between the two plots could originate from the unequal turnover rate of the organic layer, due to stand density. Further developments should involve on the one hand comparisons of energy reaching the ground and of soil temperatures in both plots and on the other hand a more acute approach of the physiological status of the foliage in particular the influence of nitrogen oversupply.

\section{Acknowledgments}

This work is part of a program supported by the 'Ministère de la Région Wallonne, Gestion des Ressources Naturelles et de l'Environnement'.

\section{References}

Andersson, F.: 1986, Water, Air, and Soil Pollut. 30, 17.

APHA: 1980, Standard Methods for the Examination of Water and Wastewater, American Public Health Association, Washington, DC. 
Aubert, G.: 1978, Méthodes d'analyses des sols, Centre Régional de Documentation Pédagogique de Marseille, Marseille.

Badot, P. M., Garrec, J. P., Millet, B., Badot, M. J., and Mercier, J.: 1988, Can. J. Bot. 66, 1693.

Bonneau, M.: 1988, Rev. For. Franc. 60, 19.

Bremner, J. M.: 1965, in C. A. Black, D. D. Evans, L. E. Ensminger, J. L. White, F. E. Clark, and R. C. Dinaver (eds.), Methods of Soil Analysis (part 2). Chemical and Microbiological Properties, American Society of Agronomy, Inc. Publishers, Madison, p. 1179.

Bruinsma, J.: 1963 Photochem. Photobiol. 2, 241.

Buldgen, P., Dubois, D., and Remacle, J.: 1982, in Ph. Lebrun, H. M. André, A. de Medts, C. GrégoireWibo, and J. Wauthy (eds.), New trends in soil biology; proceedings of the VIIIth international colloquium of soil ecology, Louvain-la-Neuve, p. 109.

Buldgen, P., Dubois, D., and Remacle, J.: 1983, Soil Biol. Biochem. 15, 511.

Buldgen, P., Cajot, O., Montjoie, A., and Remacle, J.: 1984, Physio-Géo 9, 47.

Duchaufour, Ph.: 1977, Pédologie. l. Pédogénèse et classification, Masson, Paris.

Findenegg, G. R.: 1987, Plant Soil 103, 239.

Forschner, W. and Wild, A.: 1987, in P. Mathy (ed.), Air Pollution and Ecocystems, Kluwer Acad. Publ., Dordrecht, Holland, p. 604.

Godbold, D. L. and Hütterman, A.: 1986, Water, Air, and Soil Pollut. 31, 509.

Godbold, D. L., Fritz, E., and Hütterman, A.: 1987, in P. Mathy (ed.) Air Pollution and Ecosystems, Kluwer Acad. Publ., Dordrecht, Holland, p. 864.

Hambuckers, A. and Remacle, J.: 1987, in P. Mathy (ed.) Air Pollution and Ecosystems, Kluwer Acad. Publ., Dordrecht, Holland, p. 814.

Hauhs, M. and Wright, R. F.: 1986, Water, Air, and Soil Pollut. 31, 463.

Hauhs, M. and Ulrich, B.: 1989, Nature 339, 265.

Haynes, R. J. and Goh, K. M.: 1978, Biol. Rev. 53, 465.

Kandler, O., Miller, W., and Ostner, R.: 1987, Allg. Forstz. 27/28/29.

Knabe, W.: 1984, Wiss. Umw. $2,51$.

Leggett, J. E. and Gilbert, W. A.: 1969, Plant Physiol. 44, 1182.

Martinez, A. T., Montes, C., Toutain, F., and Mangenot, F.: 1980, Rev. Ecol. Biol. Sol. 17, 307.

Matzner, E., Murach, D., and Fortmann, H.: 1986, Water, Air, and Soil Pollut. 31, 273.

Mitchell, C. D. and Fretz, T. A.: 1977, J. Am. Hortic. Soc. 67, 81.

Oren, R., Schulze, E.-D., Werk, K. S., and Meyer, J.: 1988a, Oecologia 77, 163.

Oren, R., Werk, K. S., Schulze, E.-D., Meyer, J., Schneider, B. U., and Schramel, P.: 1988b, Oecologia $77,151$.

Petersen, R. G. and Calvin, L. D.: 1965 in C. A. Black, D. D. Evans, J. L. White, L. E. Ensminger, and F. E. Clark (eds.), Methods in Soil Analysis. Part 1, American Society of Agronomy Inc. Publishers, Madison, p. 54.

Reemstma, J. B.: 1986, Allg. Forst. J. 157, 196.

SAS: 1985, User's Guide: Statistics, SAS Institute Inc., Cary, North Carolina.

Schlegel, H., Godbold, D. L., and Hütterman, A.: 1987, Physiol. Plant. 69, 265.

Schneider, D.: 1976, Wat. res. 8, 31.

Schulze, E.-D.: 1989, Science 244, 776.

Ulrich, B., Mayer, R., and Khanna, P. K.: 1980, Soil Sci. 130, 193.

Van Loon, J. C.: 1985, in P. J. Elving, J. D. Winefordner, I. M. Kolthoff (eds.), Chemical Analysis.

Volume 80 , John Wiley and Sons, New York.

Van Praag, H. J. and Weissen, F.: 1985, Plant Soil 83, 331.

Van Praag, H. J. and Weissen, F.: 1986, Tree Physiol. 1, 169.

Van Praag, H. J., Weissen, F., Sougnez-Remy, S., and Carletti, G.,: 1985, Plant Soil 83, 339.

Weissen, F. and Van Praag, H. J.: 1982, Bull. Soc. Roy. For. Belg. 90, 1.

Weissen, F., Letocart, H., and Van Praag, H. J.: 1983, Bull. Soc. Roy. For. Belg. $2,1$.

Weissen, F., Hambuckers, A., Van Praag, H. J., and Remacle, J.: 1990, Plant Soil 128, 59.

Wyttenbach, A., Bajo, S., Tobler, L., and Keller, T.: 1985, Plant Soil 85, 313.

Zöttl, H. W., and Hüttl, R. F.: 1986, Water, Air, and Soil Pollut. 31, 449. 